Peter N. Thuynsma

Peter Thuynsma succeeded Eskia' Mphahlele as Professor of African Literature at the University of the Witwatersrand, Johannesburg. He enjoyed Mphahlele's tutelage in Zambia and at the University of Denver (USA) and, with him, codirected the Council for Black Education and Research in Soweto. E-mail: peter.thuynsma@up.ac.za
Tribute

\section{Esk'ia Mphahlele remembered}

The phrase 'affable to a fault' could well be the severest understatement to characterise Esk'ia Mphahlele. He related warmly to everyone and did so with a natural and consummate ease. People meant everything to him and life was forever ripe with metaphor and analogy. He would cradle experiences, mull them over, toss them about, prod here and tickle there to extract and savour. All this coupled with a comical gait of flaying arms and a thunderous laughter made of him both a delightful caricature and a sage!

Wherever he went people wrapped him in his weighty reputation - yet he, in his immense ordinariness, seemed blissfully unaware of it. In every audience, be it one or several, he found an opportunity to learn and to teach. Everyone seemed to know of his writings, of his thinking, and however much they may have been daunted, they enjoyed the ease with which his charm and utter ordinariness disarmed them. And then his natural and almost instinctive mentorship kicked in.

I once referred to Professor Mphahlele as the Dean of African letters; he frowned disapprovingly because he wore his scholarship and connoisseurship quite lightly. Yet he was happily vain, and photographs over the past 15 years or so will show amusing changes in his hair and beard styles. But behind his appearance, behind his resplendent African prints, he was ready to burst into fits of laughter, dispense solemn wisdom, or listen intently. Zeke was humour at its wittiest, laughter at its most full-throated, and wisdom at its most profound. Here was social comment at its most honest, political criticism at its sharpest, and mentoring at its most tender and fatherly!

Prior to 1979, he published as Ezekiel Mphahlele. Upon his return to South Africa, after twenty years in exile, came a name change to Es'kia Mphahlele. Although only privately dramatic, this name change underscored an unusually heavy dependence on personal experience, a strong folk-sensitivity and frequent wrestling with the condition of exile. 
It is not merely the exile on alien soil that dominates his work, but also the exile from ancestral soil. These features characterize his personality and his writing. It is out of this material that he has hewn two autobiographies, three novels, more than 25 short stories, two verse plays and a number of poems. Add to these two edited anthologies, essay collections, more than 160 single essays and significant public addresses, several awards and a Nobel Prize nomination for Literature, and what emerges is to me a veritable Dean of African Letters.

As a young reader, Mphahlele seized upon the maxim that'a story had to be well told.' It became the simple credo that drove his work along - all his work. It is reflected in his critical criteria and the corpus of his creative writing. He preferred to view life as framed experience, ordered and patterned into a story. And if this is not an extraordinary trait in a writer, as Mphahlele's mainstay it is of major critical consequence.

Personal experience, whether fictionalized or not, formed his creative impulse. Both its simplicities and its complexities determine the lives of his characters and become microcosmic of the South African experience on one level, and of the more specific Black South African experience on another. His work, both critical and creative, became a forum in which he examined himself, feeling experience spinning around him and dancing past. His writing is less successful when he was unable to feel an incident as real or when he could not identify with its emotional core. He was, in fact, locked in a constant discourse with the experiences of his own life.

Mphahlele was born in Marabastad, outside of Pretoria, in 1919, but was soon taken to live with his paternal grandmother in the rural Northern Transvaal (now the Limpopo Province) near Pietersburg (Polokwane), in the village of Maupaneng. These were less than happy childhood years under his tyrannical paternal grandmother; his first autobiography, Down Second Avenue (1959), records her harshness alongside images of fearful, towering mountains. It was a period of fear and loss, of bewilderment, displacement and, to a minor extent, alienation. But these years also saw the forging of a sense of storytelling and a growing awareness of the need to shape experience:

Looking back to those first fifteen years of my life - as much of it as 1 can remember

- I cannot help thinking that it was time wasted. I had nobody to shape them into a definite pattern. Searching through the confused threads of that pattern, a few things keep imposing themselves on my whole judgment. My grandmother; the mountain; the tropical darkness in which glowworms seemed to try in vain to scatter; long black tropical snakes; the brutal Leshoana river [...] cattle, boulders; world of torrential rains; the solid shimmering heat beating down on yearning earth; the romantic picture of a woman with a child on her back and an earthen pot on her head, silhouetted against the mirage. (18) 
He learned how to make it through each day; learned how to survive. And these became lessons excellently learned, for when the country boy returned to Pretoria a tough ghetto life lay in wait. Some of the early obstacles came at school: in the Fifth Grade he was told he was 'backward': 'The principal said I was backward. My aunt said I was backward. So said everybody. My mother did not know. I had no choice but to acknowledge it' (47). Despite it all, there emerged a boy who ferociously consumed anything he could learn. His determination resulted in a teacher's certificate from Adams College, Natal, in 1940, and matriculation by correspondence studies two years later, while working as a teacher and shorthand typist at the Ezenzeleni Institute for the Blind in Roodepoort, west of the Johannesburg city centre. He went on to teach English and Afrikaans at Orlando High School in what is today Soweto, until he was banned from teaching in 1952 for campaigning against the Bantu Education proposals. The years 1952-53 saw him return to Ezenzeleni as secretary, and in 1954 he entered his first brief exile in what was then Basotholand, as a teacher in Maseru.

Academic honours began with his BA degree in 1949. A BA Honours degree followed in 1955 and a Masters degree, with distinction, in 1957. The University of South Africa awarded all three degrees, and studies were conducted via correspondence. The MA was the first cum laude degree to be awarded to a Black South African, and it obliged the University of South Africa to arrange an entirely separate graduation ceremony. Mphahlele's PhD was granted in 1968 by the University of Denver, USA, and his first honorary degree of Doctor of Humane Letters was conferred by the University of Pennsylvania in 1982. An equivalent tribute came from the University of Colorado in 1994. Similar honours followed when the University of Natal awarded him their Doctor of Literature in 1983, and Rhodes University conferred their highest academic accolade in 1986. In the same year, the French government awarded him the Ordre des Palmes medal in recognition of his contribution to French language and culture. In 2000, Nelson Mandela awarded him the Order of the Southern Cross. Several other honorary doctorates followed.

Ghetto life in South Africa could hardly anticipate such academic accolades. Among the scant career options available after he was barred from teaching in 1952 was a post as a journalist, and his love for writing was indeed strong enough to make him join the staff of Drum magazine in Johannesburg. In his short stay with this groundbreaking magazine, he held the posts of political reporter, sub-editor and fiction editor but, discontented with his role as a journalist and deeply disillusioned by the South African situation, he resolved in 1957 to leave for a life in exile. This led him to Nigeria, France and Zambia, and a double sojourn in the USA. Twenty years later, in 1977, he returned to his native South Africa.

Mphahlele's career is in spatial terms a map of both Africa and the world. Yet against such a broad and colourful canvas, his creative involvement with the African experience has been restricted to specific themes. His work shows a keen awareness of 
the strength of black women, yet he certainly does not develop his women characters as feminist scholars would prefer - although his novel Chirundu (1979) may well be an exception. He often depicts the ambivalence of the African personality, caught between a rural and urban sensibility, and his human landscape inevitably eclipses physical setting. The white-black encounter stalks his themes.

Mphahlele thrived on the communal point of view; always coming to grips with his milieu, with his Pan-African world-view. He was constantly engaged in some form of self-definition - a wrestling that is rooted in cultural imperatives. He was determined to write about something and not of something as he addressed the African experience.

It is indeed his ordinariness, his modesty, his rooted humility, that endeared him to all who knew him. We should also remember Zeke the man, the father and the friend. But there was also the comic, the fun-loving character whom so many of us got to savour. I can still visualise a hilarious incident the first time I joined the Mphahlele family table for a meal - I was astonished to see him in earnest, secret negotiations with the 9 and 12 year old Chabi and Puso - bold-facedly bribing his young sons for their portions of pudding and custard (because Ma Rebecca had refused him a second helping!).

Then there is his commentary on township funerals in an unusual story that promised to be one of a series called Tales from Birdland. Loosely built on Chaucer's Parliament of Fowles, he satirised the interminable posturing at the expense of the unfortunate corpse. In his later years Zeke's critical eye also focussed on the transmutations in African culture -specifically the way South African youth often misconstrue $u b u n t u$ for their own purposes. He balked at the hollowness of the current clichés like son of Africa and son of the soil. Why, he asked, is there less reliance on defining the self in one's own South Africanness, one's own community responsibilities? And in that lies his legacy - a scintillating catalogue of academic and community achievements that charges us to continue its course by using what we've learned towards building people and our communities.

At his funeral, a nine-year old girl was among the youngest recruits to one of Zeke's reading circles which flourish in the villages that abuts Lebowakgomo and his childhood Maupaneng. Her very presence was fine testament to how Zeke's example will endure. May we all do our part.

December, 2008

Johannesburg, South Africa 